\title{
O sagrado erótico em Je vous salue, Marie, de Jean-Luc Godard
}

\author{
The erotic sacred in Jean-Luc Godard's Je vous salue, Marie
}

Leyla Thays Brito da Silval

Resumo

\begin{abstract}
Este artigo tem como objetivo compreender a elaboração artística da matéria sagrada no filme Je vous salue, Marie, de Jean-Luc Godard, a partir do conceito de Erotismo desenvolvido por Georges Bataille. $\mathrm{Na}$ tradição bíblica, há um silenciamento em relação à experiência espiritual e corporal da Virgem Maria, ao longo da gestação de Jesus. Godard, ao retomar a narrativa da "concepção imaculada", interessa-se pelos processos psíquicos e somáticos da Virgem. O texto fílmico de Je vous salue, Marie constitui uma provocação a partir do conflito entre a castidade de Maria e as idiossincrasias eróticas do seu corpo. Afastada do toque masculino de José, a personagem acolhe o Eros transcendente de Deus, porém, ao mesmo tempo, seu corpo libidinoso não silencia o desejo sexual. Para Bataille, a sexualidade estaria na arqueologia de todas as modalidades de amor, até mesmo das que se voltam à transcendência divina. Nesse sentido, verificaremos a articulação do erotismo feminino com a matéria sagrada, enquanto concepção estética e filosófica do filme.
\end{abstract}

Palavras-Chave: Sagrado, Erotismo, Corpo, Godard, Bataille

\section{Abstract}

This paper aims to read the artistic elaboration of the sacred matter in Jean-Luc Godard's film Je vous salue, Marie, from the concept of eroticism developed by Georges Bataille. In the biblical tradition, there is a silence concerning the spiritual and corporal experience of Virgin Mary when she was pregnant with Jesus. Resuming the narrative of the "immaculate conception", Godard is interested in the psychic and somatic processes of the Virgin. The filmic text of Je vous salue, Marie is a provocation on the conflict between Mary's chastity and her body's idiosyncrasies. Purposefully keeping herself away from Joseph's masculine touch, the character embraces God's transcendent Eros, but at the same time, her libidinous body does not silence sexual desire. For Bataille, sexuality would be in the archaeology of all modalities of love, even those aiming at divine transcendence. In this sense, we will examine the articulation of the female eroticism with the sacred matter as the aesthetical and philosophical concept of the film.

Key words: Sacred, Eroticism, Body, Godard, Bataille

IProfessora Adjunta no Departamento de Ciências das Religiões da Universidade Federal da Paraíba - UFPB, Doutora em Literatura e Cultura pela UFPB e Coordenadora das atividades do Eros: Núcleo de Estudo e pesquisa em Literatura e Erotismo. Contato: leylahestia@ hotmail.com. Artigo recebido em 11/05/2018 e aprovado em $22 / 10 / 2018$. 


\section{Introdução}

O filme Je vous salue, Marie, de Jean-Luc Godard retoma o tema bíblico da "concepção imaculada" de Jesus no corpo da Virgem Maria. A partir de uma moldura contemporânea, a narrativa se passa na França dos anos 80, em que Maria (Myriem Roussel), uma jovem estudante, que trabalha no posto de gasolina do pai, tem um namorado, José (Thierry Rode), um jovem taxista, com quem mantém uma relação há dois anos, sem consumação sexual. A jovem recebe a notícia de que terá um filho, cuja paternidade não é humana. Ao se confirmar a gestação, José obviamente não crê na castidade da amada.

A composição do filme lança algumas provocações, por vezes blasfematórias, no trato com a relação corpo-alma. Deus, em seus aspectos transcendentes e absolutamente espirituais, será questionado e insultado, pela inescapabilidade da condição carnal humana, a partir dos constantes primeiros planos e primeiríssimos planos sobre o corpo de Maria.

Quando lançado em 1985 na França, o filme Je vous salue, Marie, sofreu uma série de perseguições e retaliações. Em Nantes, por exemplo, os católicos faziam manifestações contra a "indecência" e "obscenidade" no trato godardiano na feitura fílmica da Virgem. No Brasil, a reação não foi diferente, sendo a exibição proibida pelo presidente Sarney, em 1986.2 O caráter polêmico do filme dá-se, sobretudo, pelo enfoque na sexualidade e sensualidade do corpo, a partir de nus frontais da personagem Maria. $O$ tabu do corpo da Virgem será confrontado por esses inúmeros enfoques nos seios, nádegas e genitália da personagem.

Por outro lado, a imprensa católica francesa, numa disposição e sensibilidade em reafirmar a sua moralidade na obra de Godard, centra-se na ideia de que Je vous salue, Marie, ao transpor o tema da gestação casta para o corpo de uma jovem do século XX, engendra uma atualização dos valores morais e religiosos que normatizam a sexualidade cristã. Conforme essa perspectiva, apesar da flagrante obscenidade, a densidade espiritual do filme, na angústia de Maria e na sua relação com José, acolhem uma configuração legítima e respeitosa do mistério da Virgem( por "configuração legítima", entenda-se a supremacia dos valores espirituais cristãos em detrimento da sexualidade e erotismo humanos.) No fim de contas, considerando toda a licença poética da estética godardiana, o filme apresentaria, segundo a imprensa católica, uma conformação com o discurso eclesiástico. (MALABRE, 2012.)

Contudo, compreendemos que o texto fílmico de Je vous salue, Marie constitui uma provocação a partir do paradoxo entre a disposição de Maria em manter-se casta, para a concepção de Jesus, e a presença e idiossincrasias do seu corpo carnal, sensual, que dizem do seu desejo de realização sexual e erótica. Se, por um lado, a personagem Maria assume uma postura de castidade, recusando o toque de José, por outro, o texto-imagem do filme, centrado no corpo da mulher, diz do conflito erótico entre corpo e alma, no processo de sua formação enquanto mãe-virgem do filho de Deus. Nesse sentido, supomos que a sacralidade da maternidade de Maria resulta mesmo dessa ambiência dramática, em que o erotismo feminino se mescla com a castidade. A corporeidade crua diz muito mais de uma concepção estética e filosófica do sentido de sagrado veiculado pelo filme do que de uma banalização e dessacralização do corpo da mãe do Cristo.

\footnotetext{
2 No acervo do jornal O GLOBO pode-se verificar uma nota divulgada no dia 4 de fevereiro de 1986, em que o presidente Sarney decide vetar o filme "para assegurar o direito de respeito à fé da maioria da população brasileira."

acervo.oglobo.globo.com / fatos-historicos/sarney-proibe-filme-de-godard-scorsese-polemiza-em-ultima-tentacao-decristo-9980245\#ixzz5EHVPD8jV
} 
Assim, para a análise dessa trama que articula erotismo e castidade, utilizaremos como orientação teórica a relação entre erotismo e sagrado desenvolvida na obra do filósofo francês Georges Bataille (1897-1962), que, ao longo de sua produção intelectual e artística, empenhouse por compreender a experiência sagrada como inerente ao ser humano, não a limitando, portanto, à vinculação a sistemas religiosos de crenças. Ao localizar o sagrado no erotismo, Bataille assinala, no desejo humano por completude, isto é, no anseio por ser amado, as raízes do sagrado. No percurso reflexivo do autor, o ato sexual e a corporeidade estariam na arqueologia de todas as modalidades de amor, até mesmo das que se voltam à transcendência divina. Portanto, sexualidade, erotismo e sagrado constituem categorias conceituais batalleanas aqui utilizadas para a interpretação do nosso corpus de análise.

\section{Todas as mulheres desejam algo que seja único}

A concepção virginal de Jesus no ventre de Maria constitui o grande mistério da encarnação do Cristo. Não tendo uma paternidade humana, o filho de Deus ingressa na carne por meio do Espírito Santo, a força divina operante sobre os homens. No evangelho de Lucas, a narrativa da "Anunciação" diz de como se dá a vontade divina sobre o corpo de Maria: "O Espírito Santo virá sobre ti e a força do Altíssimo estenderá sobre ti Sua sombra, por isso mesmo é que o santo que vai nascer há de chamar-se filho de Deus." (Lucas 1,35)

A vivência dessa experiência única e misteriosa não será desenvolvida em detalhes pelos evangelistas. $O$ supracitado trecho de Lucas, que, diga-se de passagem, traz nuances eróticas e sexuais da concepção, é uma campo aberto a interpretações diversas, em virtude de seu caráter elíptico e simbólico. Portanto, Godard, com Je vous salue, Marie, interessa-se pelos processos emocionais e corporais vividos pela Virgem, mediante o conhecimento do seu papel nos planos divinos. Ora, a Maria godardiana é uma jovem lidando com o grande mistério divino, sendo engendrado em seu corpo. Um acontecimento excepcional que the causa temor, angústias, questionamentos, êxtases, prazer.

O primeiro diálogo do filme dá-se entre José e Juliette (Juliette Binoche), uma jovem com quem, se supõe, José tem um caso amoroso. Se com Maria a relação de José é casta, o papel de Juliette se dá na dimensão do Eros carnal. Contudo, insatisfeita, ela reivindica mais espaço na vida do amado. "Todas as mulheres desejam algo que seja único". Como fundo musical a esta fala, tem-se a Tocata e Fuga em D menor de Bach, sugerindo o mistério, o perigo e a magnitude do desejo feminino. Não por acaso, o primeiro pensamento de Maria, em voz off, expresso logo em seguida à cena com José e Juliette, enuncia a questão axial de sua trajetória, que concerne à potência do seu desejo: "Perguntava-me se algo importante ia ocorrer em minha vida." Tal passagem, dialoga, claramente, com a fala de Juliette. Numa aproximação concreta, a partir da montagem que põe uma cena em seguida da outra, há um diálogo e conformidade entre as falas dessas mulheres. Expressas ao longo dos quatro primeiros minutos da película, tal como um prólogo, elas nos parecem sinalizar para a centralidade do filme, que estaria em localizar o desejo de Maria no âmbito do desejo de qualquer mulher. A excepcionalidade da concepção imaculada de Maria parece se desdobrar, em termos metafóricos, numa atualização da mensagem bíblica. Juliette profana e Maria sagrada falam desse "algo único" e insondável que desejamos.

A esse respeito, Georges Bataille, em seu l'Erotisme, considera o erotismo como um componente da vida interior humana. Em função dos questionamentos que o ser humano se impõe, a atividade sexual foi transformada em atividade erótica, na medida em que os sentimentos de incompletude e de descontinuidade do ser impulsionam a uma fusão com um outro ser que concretiza o objeto de desejo. A principal preocupação de Bataille é de 
vislumbrar o erotismo como elemento da experiência interior. Para tanto, como percurso epistemológico, sua proposta é de tocar uma reflexão que considere que "o erotismo é, na consciência do homem, aquilo que põe nele o ser em questão." Assim, o erotismo advém de um desequilíbrio que leva o homem a indagar-se. A dúvida, a falta de uma certeza de si e de seu futuro faz com que o ser humano perca seus contornos próprios de significação objetiva, movendo-o a um percurso interior angustiante, que irá congratular-se num outro ser, em função do qual o indivíduo, ultrapassando seus contornos e fronteiras, irá romper-se. Assim, "l'érotisme est (...) Le desequilibre dans Le quel l'être se met lui-même em question, consciemment. E nun sens, l'être se perd objectivement, mais alors Le sujet s'identifie avec l'objet qui se perd." (BATAILLE,G. 2011, p. 35). O Erotismo seria, assim, esse derramamento num outro ser, amado/a, seja ele carnal, divino, transcendente ou imanente.

A pergunta prologal de Maria, de que se algo importante aconteceria em sua vida, diz dessa experiência interior, de autoquestionamento, que irá sucumbir na fusão erótica com o divino. Maria deseja um outro excepcional; está na sua interioridade essa busca por um encontro com o mistério. A cena da Anunciação ocorre de forma a imbricar os desígnios divinos com o desejo de Maria. Gabriel, um estranho que pega o taxi de José, oferece-lhe 500 dólares para levá-lo a um determinado lugar. Ao chegar até Maria, o "anjo" vem dizer-lhe aquilo que ela já sabe em seu íntimo.A forma com que o anjo anuncia a gestação aparece interligada com o a demanda do "querer" de Maria.

- O que queres, senhorita?...Vais ter um menino".

- De quem?

- Não se faça de inocente.

Maria, com o rosto em primeiro plano, olha para o céu, quando pergunta o que de fato quer o estranho Gabriel, sugerindo, assim, reconhecer os desígnios divinos nessa visita. Tão logo a concepção é anunciada, Maria vivencia sua trajetória erótica de conflito, em que o seu corpo de mulher precisa manter-se casto. Na primeira cena, que introduz a poética do erotismo de Maria, a personagem com a mão entre as pernas inicia seu périplo, a um só tempo angustiado e prazeroso, em que a dualidade espírito-corpo passa a figurar o campo de suas indagações eróticas. Enquanto se toca, Maria reconhece: "Não escaparemos um do outro". Nesse sentido, a condição transcendente da divindade de Cristo no corpo da Virgem emoldura o conflito.

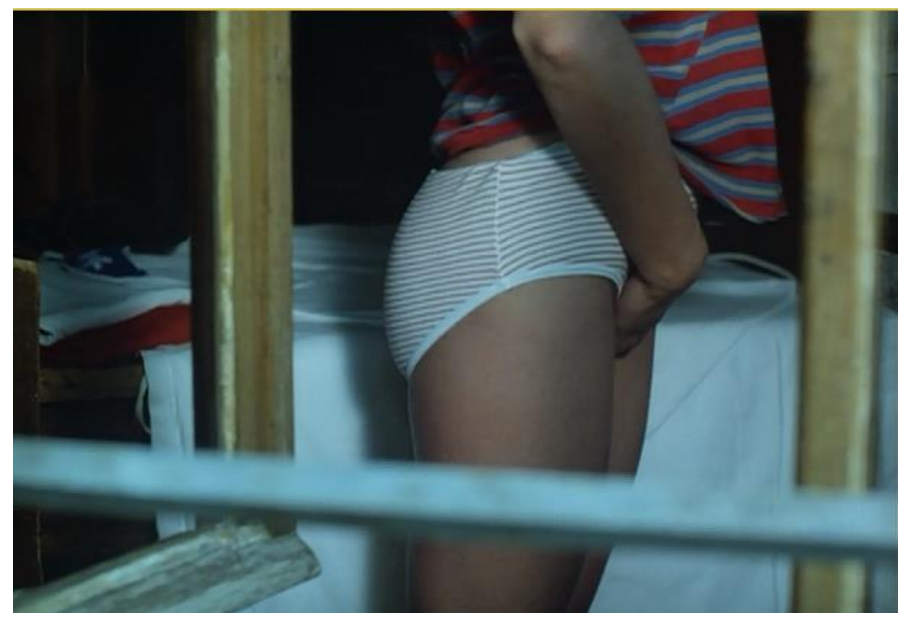


A partir de então, inicia-se a dor e prazer de Maria, ao questionar e sentir qual lugar a carne ocupa, qual sua função e articulação com o amor divino. O toque de José é interdito, porque ela foi tocada pelo Espírito Santo. Contudo, como lidar com a sensualidade da carne, do seu sexo, da sua genitalidade?

A modelagem da matéria sagrada dada por Godard em Je vous salue, Marie perpassa a experiência íntima e conflituosa de Maria, em que corpo e alma se embatem e se complementam. O signo vaginal será axial na composição estética do filme. A vivência sagrada de Maria é absolutamente humana, porque não pode apartar-se do corpo de mulher. $\bigcirc$ Deus amado toca não só seu coração, mas seu corpo, precisamente seios, ventre e vagina, ao fecundá-la. Num dos monólogos mais poéticos do filme, Maria, enquanto banha-se e apalpa os seios, num reconhecimento da maternidade, liga sua corporeidade ao amor de Deus:

E entretanto, sentia uma alegria ao oferecer assim meu corpo, ao olhar deste que se havia convertido em meu Senhor, para sempre. Ao dirigir o olhar para este ser maravilhoso, pois, na verdade, hoje como ontem, ele era, não por seu aspecto, nem por seus atos, mas sim por essa força muda que seentranhava, essa potência concentrada, tão grande, como uma montanha que se eleva para o céu e que não se pode nem medir, nem descrever, a não ser simplesmente sentir.

Enquanto esse texto é enunciado com a voz de Maria em off, as imagens revelam o jogo estético do filme em que a transcendência divina coloca-se muito próxima, quase carnal, tal como um amante a observar sua amada no momento íntimo do banho. A cena, filmada em leve plongée sobre Maria nua, concretiza as palavras "oferecer o corpo ao olhar ao Senhor". Esse enquadre parece dizer que a divindade ocupa o mesmo tempo-espaço da personagem em seu banho. Contudo, quando a voz se reporta ao próprio olhar de Maria -"ao dirigir o olhar para este ser maravilhoso," - há um corte na cena do banho para a imagem do sol nascente, o que revela a reverência aos mistérios celestiais. A um só tempo, o texto se volta ao transcendente e às sensações da proximidade do Senhor.

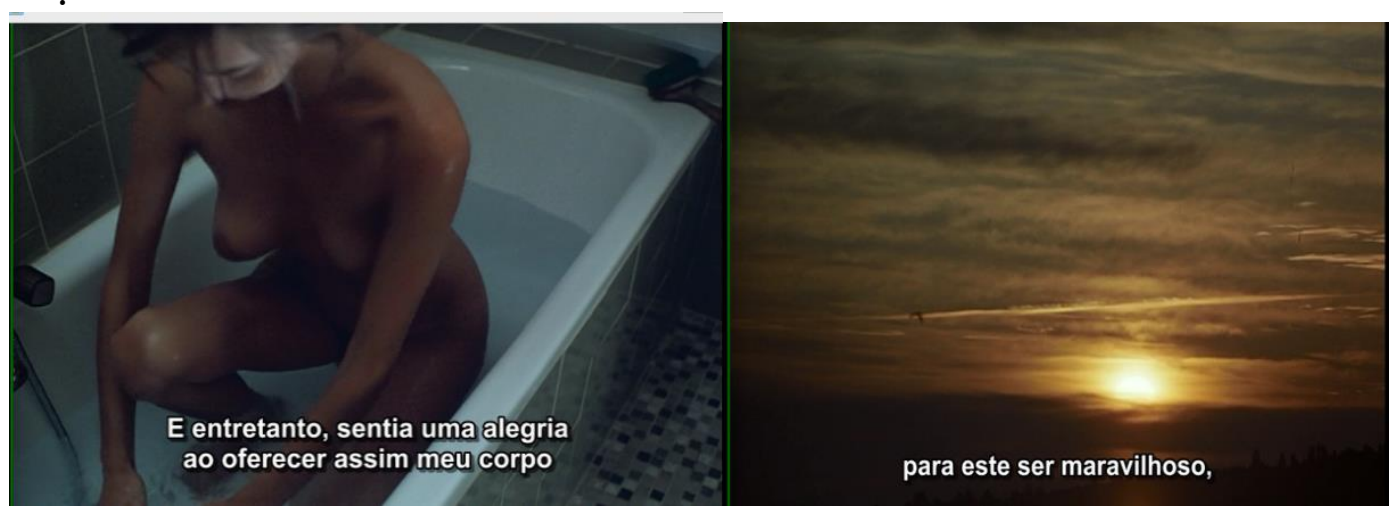

Acerca da potência sagrada, Maria diz que "não se pode nem medir, nem descrever, a não ser simplesmente sentir." As sensações, que se localizam e atuam na corporeidade são, efetivamente, condutoras ao entendimento e aproximação ao sagrado. Vale ressaltar que Maria "oferece o corpo" neste momento, e alegra-se com isso. $O$ banho se refere a uma purificação 
da carne, como também sugere os cuidados femininos após o sexo. A poética das referidas imagens parecem aludir a uma semântica do coito. A mulher recebe o amor e a potência desse mistério em seu corpo, como quem recebe o amor de um homem. Assim, se configura o erotismo sacro. Não há uma conjunção carnal, mas a poiesis fílmica realiza-se no campo semântico do desejo sexual. É pelo prazer do corpo que a Virgem reconhece o Eros divino.

A alegria da personagem (joie), ou o gozo (jouissance), em dar-se ao "ser maravilhoso" aproxima-se de uma experiência mística de entrega absoluta a um mistério, um tipo de contemplação e prazer, em que não cabe a reflexão discursiva, mas apenas o "sentir". Recorremos à proposição de Bataille para melhor expressarmos o aspecto místico do filme:

Sob o nome misticismo, não designo os sistemas de pensamento aos quais é dado esse nome vago: penso na "experiência mística", nos "estados místicos" experimentados na solidão. Nesses estados, podemos conhecer uma verdade diferente das que estão ligadas à percepção dos objetos ( $\mathrm{e}$, a seguir, do sujeito; ligadas, enfim, às consequências intelectuais da percepção). Mas essa verdade não pode ser formalizada. $O$ discurso coerente não pode dar conta dela. Ela seria mesmo incomunicável se não pudéssemos abordá-la por duas vias: pela poesia e pela descrição das condições em que é comum se chegar a este estado. (BATAILLE, 2015, p. 23)

O misticismo batailleano é vivido na solidão. No interior de si mesmo, o indivíduo tem um percurso em direção a uma fusão com um outro, com o objeto, em que o eu é apagado, dissolvido. Esse encontro fusional, em que uma individualidade dilui-se num outro ser, no caso de Maria, no ser divino, é o próprio percurso erótico. Constitui uma experiência que viola o projeto da palavra, do conhecimento lógico e da determinação sujeito-objeto. Nesse sentido, a poesia, ou melhor, as artes como um todo, seriam uma forma possível de comunicação desse processo.

\section{Maria, uma virgem erótica}

Considerando-se que a arte ocidental manifesta-se, muitas das vezes, a partir de um lugar discursivo questionador dos sistemas normativos da vida social, vale retomar as reflexões de Georges Bataille em seu livro $A$ literatura e o mal, o qual, embora se concentre nos aspectos transgressivos da arte literária, nos dá uma dimensão bastante ampla do caráter questionador fundamental da linguagem artística.

Para Bataille, toda grande obra abarca o "mal" como componente ético e estético. Para este mal artístico, pode-se dizer que não se trata de qualquer mal, mas daquele que mete em questão tabus fundamentais, como os ligados ao assassinato e a certas práticas sexuais. Nesse sentido, o mal/transgressão artístico, numa perspectiva ética e estética, clarifica as armadilhas dos interditos, desvelando as nuances e contradições dos desejos humanos. Vale aqui uma ponderação do aspecto transgressor do filme, a partir do conceito de "mal", como componente estético, que reconfigura a matéria sagrada na obra em análise.

O tabu da sexualidade da virgem que engendra o filho de Deus emoldura a poiesis do filme. Maria decide manter-se virgem, mas isso não significa dizer que seu corpo, seus desejos, não atuem. A castidade não se dá por um vínculo a uma doutrina ou instituição religiosa. $A$ escolha da moça deve-se a um processo íntimo e solitário de perquirição e provas colocada a si 
mesma. Com o fruto sagrado em seu ventre, a jovem inicia uma série de elucubrações sobre a alma e o corpo que se dão num processo angustiado entre desejo e castidade.

Indo ao encontro de José, Maria passa por uma loja de cosmético e, hesitante, toca um batom vermelho, signo da sedução feminina que a jovem acolhe em sua corporeidade. $O$ objeto-batom apresenta uma carga de importância dramática, no desenrolar da trama fílmica, porque sinaliza para o desejo sexual de Maria e põe em evidência o conflito entre corpo e alma que a personagem vive. $O$ corpo eroticamente oferecido ao Deus também deseja o homem. No apartamento de José, o signo corpo, na fala de ambos, flutua entre o lugar de soberano e de subordinado em relação à alma. As reivindicações de José solicitam a Maria o lugar do corpo. Há dois anos eles têm um relacionamento, mas a jovem evita a conexão sexual. José pergunta-Ihe : "E o corpo?" "Por que meu corpo te dá asco?" Maria, em contrapartida, Ihe questiona: "Por que não acreditas que o espírito age sobre o corpo?". Para o rapaz, é o corpo que age sobre o espírito. Maria revela o medo dessa possibilidade em que o corpo é senhor. Discursivamente, a moça acompanha e defende o espírito em detrimento do corpo, que é, como ela afirma, "o irmão asno", ao ler um uma biografia de São Francisco de Assis. Contudo, a ironia poética revela o corpo da jovem em seu desejo e sedução em relação, tanto a Deus quanto a José. Para que ele acredite que o mistério divino a tocou e que a vida que leva no ventre não provém da relação com um homem, ela pede para que o rapaz a toque entre as pernas.

Na sequência, Maria se diz compreender como viver sua castidade autenticamente, sem negar a corporeidade. $O$ reconhecimento do desejo próprio e do corpo é a via para uma castidade legítima, fruto de uma "experiência interior", intransferível. Enquanto troca-se, despindo-se inteiramente para vestir-se com um tipo de bata branca virginal, ela afirma: "Quero que a alma seja corpo e que não se diga que o corpo é alma, já que a alma será corpo." Nesse jogo semântico entre corpo e alma, a corporeidade assume uma posição de veiculadora da alma. A experiência de castidade de Maria precisa ser autêntica, passando, sobretudo, pelas possibilidades e angústias movidas pelo desejo, precisa ser uma decisão resultante de um aprendizado íntimo, e não de obediência e resignação a um dogma.

Num processo de angústia erótica, em que o desejo Ihe revira o corpo, Maria alcança a compreensão de que "ser casta é conhecer todas as possibilidades, sem perder-se nelas." Vejase que a afirmação do próprio desejo sexual, o confronto com ele diz da ética de que fala Bataille, quando se refere ao "mal" artístico. Maria se confronta com sua interioridade erótica sem rejeitá-la de todo. Perceber as nuances e camadas de desejo sexual, sem hipocrisias e silenciamentos, é o que caracteriza a ética artística em Godard. A castidade da virgem dá-se pelo enfrentamento do que coloca em perigo o projeto divino, que não prescinde da castidade materna. "Um ser altivo aceita lealmente as piores consequências de seu desafio. Por vezes até precisa ir ao encontro delas. A parte maldita é a parte do jogo." (BATAILLE, 2015, p.27)

Godard compreende o amor pela via do corpo, seja o amor transcendente de Maria por Deus, seja o amor pelo homem José. Na cena clímax da intriga narrativa, ocorre o entendimento de José de como amar a castidade da amada. Maria intenta ensiná-lo o gesto com o qual deve ser tocada pelo homem. $O$ corpo assume o papel de mestre desse conhecimento do desejo casto da mulher.

José, sempre imerso no desejo carnal, pede a Maria para vê-la nua, uma vez que irão casar-se, acreditando que a batalha pode ser ganha nesse encontro. A jovem aceita o pedido. José antecipa-se no encontro e surpreende Maria sem as peças intimas, portando apenas uma camiseta. Ele a toca no braço, ela o empurra e, em desespero, cerra os punho, em aflição, como numa atitude de pedido de perdão a Deus. A câmera em plongée sobre Maria, sugere

\section{5}


um opressão moral, como diz Marcel Martin, o efeito de filmagem de cima para baixo "tende a apequenar o indivíduo, a esmagá-lo moralmente." (MARTIN, M. 2013, p. 44).

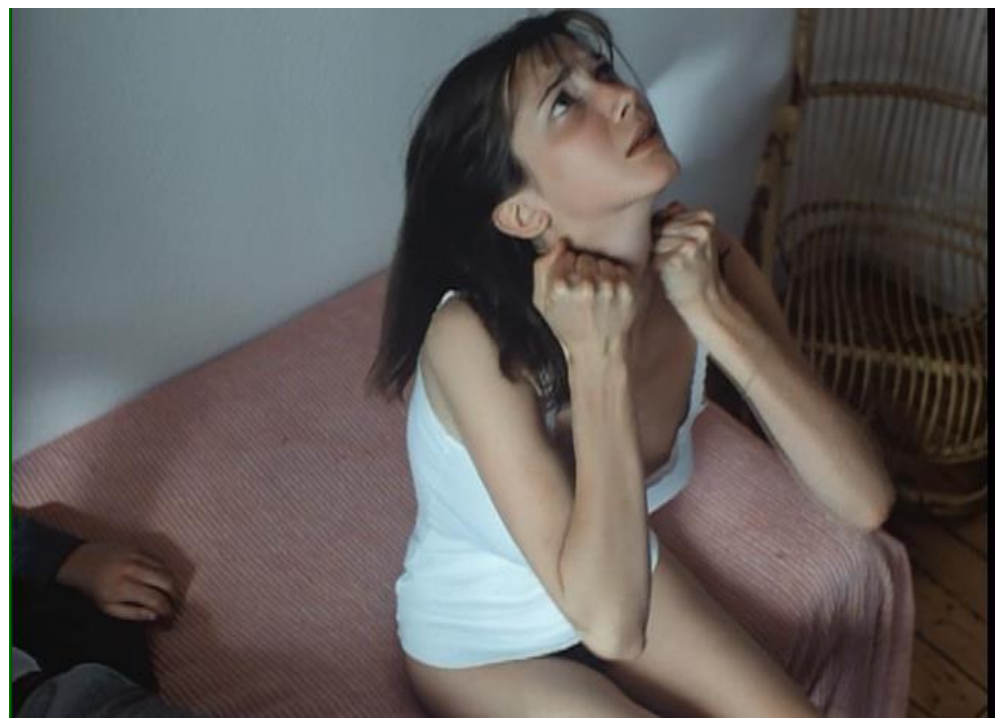

Após esse momento de dor pelo desejo erótico de José, Maria quer manter-se casta e precisa ensinar seu homem o percurso do seu erotismo virginal. Ela pede para que ele diga que a ama. Por quatro vezes José repete, "Eu te amo", tocando o ventre da jovem. Maria não aceita esse toque, porque não está adequado.

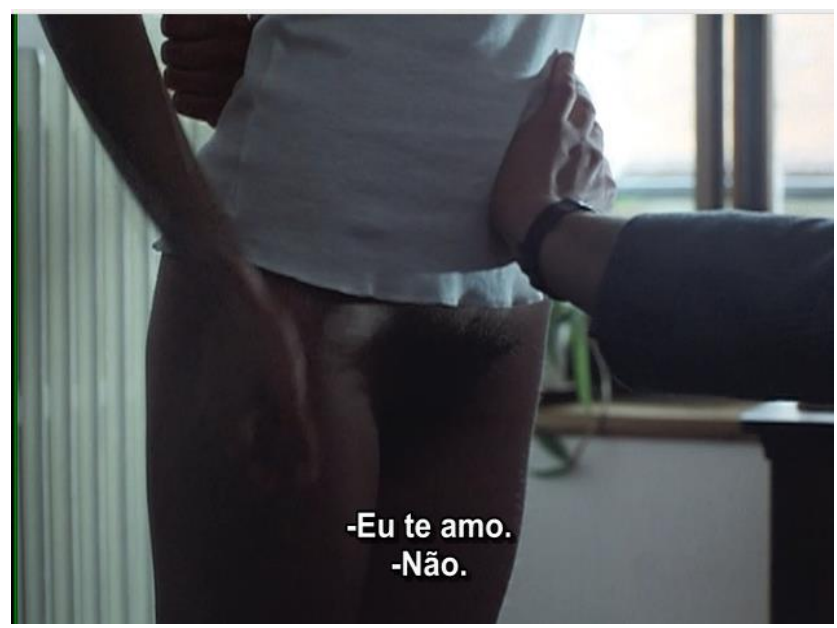

Sem entender, José pede "o porquê" da recusa,então o anjo Gabriel, como um deus ex machina, intervém e lhe diz que é "a lei". Ele toca a amada mais uma vez e, novamente, ouve um "não". Sinos tocam, anunciando a epifania que estar por vir. José toca levemente o ventre de Maria e, logo em seguida, afasta a mão. Enfim, recebe um "sim":

"É isso, eu te amo?"

"Sim". 
Por mais duas vezes ele toca e afasta a mão, enquanto diz "te amo", enfim, compreendendo qual amor e toque Maria espera. Se antes havia o desejo erótico de possuir o corpo da virgem, o toque aceito sugere um amor que não impõe a sexualidade. A mão sobre o ventre, com um momento de distanciamento, aponta para esse espaço que José precisa dar a Maria, enquanto ela gera o filho de Deus.

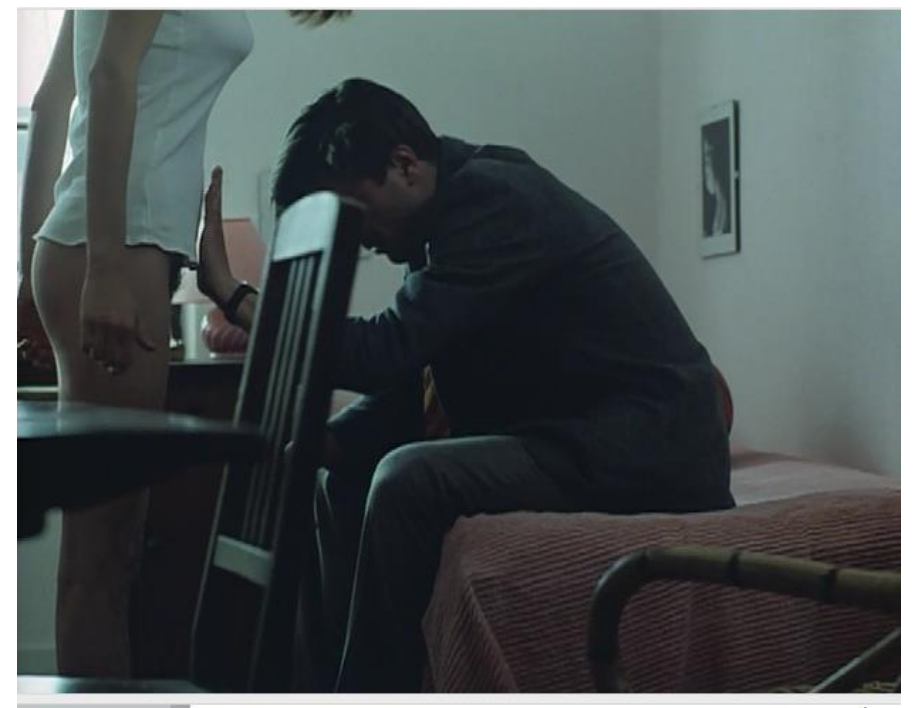

Nesse sentido, a castidade de Maria não se trata de uma recusa ao pecado, a uma ética. Colocar-se nua ante o homem que a deseja ardentemente, com o intuito de ensinar-lhe o caminho desse desejo casto, afirma a liberdade da escolha, para que assim o homem, tomado pelo conhecimento da força sagrada que mobiliza Maria, a acompanhe. A esse respeito diz a jovem: "Se considerarmos o pecado da maneira correta, ele não existe, ele desaparece, como o casulo da libélula, quando lutam por sua liberdade."

\section{Maria, um corpo cansado de alma}

A liberdade de Maria é tamanha que, a todo o momento, ela vive conflitos internos movidos pelo constante questionamento. A dualidade corpo-alma, ciclicamente, leva a personagem a buscar compreender o que está na ordem do divino e aquilo que lhe diz respeito, como mulher. Não se trata de um ato resignado. Maria, no fim de contas, parece busca compreender o mistério do seu próprio desejo, na medida em que este não se dá inteiramente a conhecer. $O$ acolhimento do Verbo no corpo leva a um contentamento inexplicável, mas, enquanto experiência mística, dá-se em situações de duração limitada, uma vez que não se pode viver em êxtase permanentemente. A imersão erótica de Maria nos braços divinos tem hora para acabar, de modo que surge uma nova forma de ser mediante essa experiência. $O$ erotismo, como se disse, é a perda da individualidade, uma diluição do sujeito no objeto amado, um experiência de morte, de gozo, uma pequena morte. Contudo, a recomposição da individualidade faz-se necessária para que a vida seja preservada. Mesmo no mergulho erótico sagrado, Maria revela ao espectador nuances de sua individualidade. Uma mulher que deseja, que tem o corpo marcado pela sensualidade erótica e que recebe a divindade por esta via. $\bigcirc$ reencontro com seu eu-mulher se inicia após a aquiescência de José 
em permanecer ao seu lado, oferecendo o amor que ela, naquele momento, precisa receber, o amor sem o contato sexual.

Grande parte dos vinte minutos finais do filme concentra-se na passagem da Mariavirgem para a Maria que acena à realização do ato sexual em carne. Numa das passagens mais emblemáticas da complexidade do desejo dela, temos um belíssimo texto, com voz em off, expressando o drama interno da personagem, que passará a questionar a natureza divina, e a definir o papel central do corpo na relação com o sagrado:

Desejar não é deitar-se à força, mas voltar-se para si, passo a passo, até a eternidade. Não é preciso o buraco da boca para comer, nem o cu para engolir o infinito. Terá que colocar o cu na cabeça e, assim, descer até o nível do cu, e ir-se à direita ou à esquerda, para chegar mais longe. Deus é um vampiro, que quis que eu sofresse nele, e se aproveitava da minha dor. Maria é um corpo cansado de alma, eu sou uma alma prisioneira de um corpo. Minha alma me causa dor no coração... é minha boceta. Eu sou uma mulher, embora não gere a meu homem por minha boceta.

Maria, nua, estendida sobre a cama, reverbera seus pensamentos em elucubrações densas sobre a relação entre corpo e alma. Com se vê, esse trecho diz de todo o percurso do desejo da personagem ao longo do filme. O corpo, em imbricação com a alma, se revelou como instrumento para se alcançar a eternidade divina. Enquanto Maria fala na eternidade, a câmera, em contra-plongée, mantem-se na luminosidade do sol de modo a demarcar que a palavra "eternidade" se liga à transcendência divina. A dualidade continua com o enfoque na carne, em que as palavras "boca" e "cu", também remetem a um tipo de eternidade e mistério do absoluto de Deus. Duas eternidades estão postas a da carne e a celestial. Transportar o ânus à cabeça, para se chegar mais longe. Na composição das imagens, assim que a voz em off da jovem enuncia o termo "longe", mais uma vez a câmera se volta ao céu iluminado pelo sol. A escuridão do ânus é, segundo Maria, via para se chegar à luminosidade divina. É no interior do corpo, nas partes baixas, que se pode alcançar as alturas, de modo que Deus se deixa ver pela obscuridade corpórea. Essa aproximação do ânus com o sol parece dialogar com o texto $O$ ânus solar de Georges Bataille, que apresenta o ânus como a via obscura em que o sagrado se deixa entrever.De acordo com Schollhammer:

Para Bataille, a elevação em direção à luz solar faz com que o sol absorva, para sua escuridão, o adorador que insiste em contemplar o disco iluminado apesar da dor que isso lhe possa provocar. A luz do sol é a expressão exterior de uma obscuridade interior. (...) o sol copula com a noite e se abre para a escuridão no interior de tudo o que é visível, como um ânus - " o buraco mais escuro de todos os buracos."- no qual tudo é absorvido, implode e desaparece." (Schollhammer, 2007, p. 87)

O sol-ânus, como observa Schollhammer, diz da inapreensibilidade do sagrado que demanda ao ser humano um nível de loucura. O sol é a luminosidade suprema, mas incandescente, não se pode olhá-lo diretamente sem se perder.

Quanto ao signo feminino da vagina, Maria parece aproximá-lo ao coração. A palavra francesa con, o órgão sexual feminino, identifica-se com coração. A alma como algoz, pelo 
excesso da espiritualidade, machuca a vagina que, ao logo de toda essa fala, aparece em primeiro plano. O deus, ao tomar o corpo da jovem, apossa-se de seu sexo. O que ela busca, a partir de então, será reapossar-se de sua genitalidade, até então, não tocada ao longo do filme.

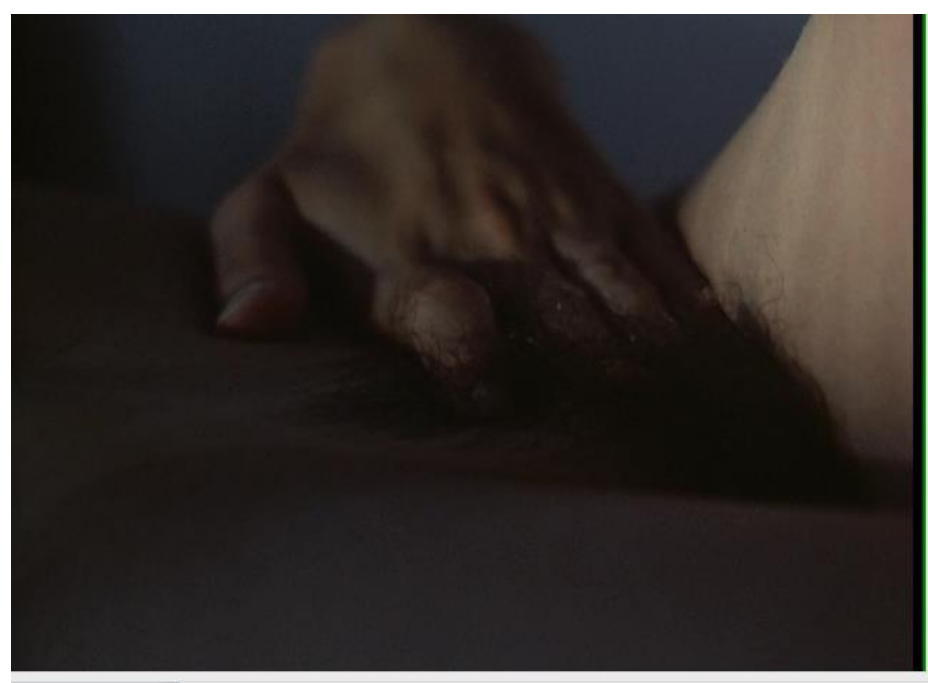

Após ter tido a criança e cumprido sua missão virginal, inicia-se o reencontro com sua individualidade sexual. A poética fílmica, ao retomar o signo imagético do "batom-vermelho", devolve a individualidade corporal e erótica da mulher-Maria. Em primeiro plano surge o caminhar da personagem com seus sapatos altos, mais um signo do locus feminino. Ao entrar no carro, o anjo Gabriel the aparece e enuncia a saudação canônica "jê vous salue, Marie" (versão francesa da expressão latina "Ave Maria".) Ao ouvir a evocação do anjo, Maria assume o seu lugar, a partir do gesto de passar batom sobre os lábios. $\bigcirc$ filme conclui-se com um close da boca vermelha aberta, ao máximo, retomando o mistério do ânus-solar que a personagem evocara quando da sua transição para essa nova condição.

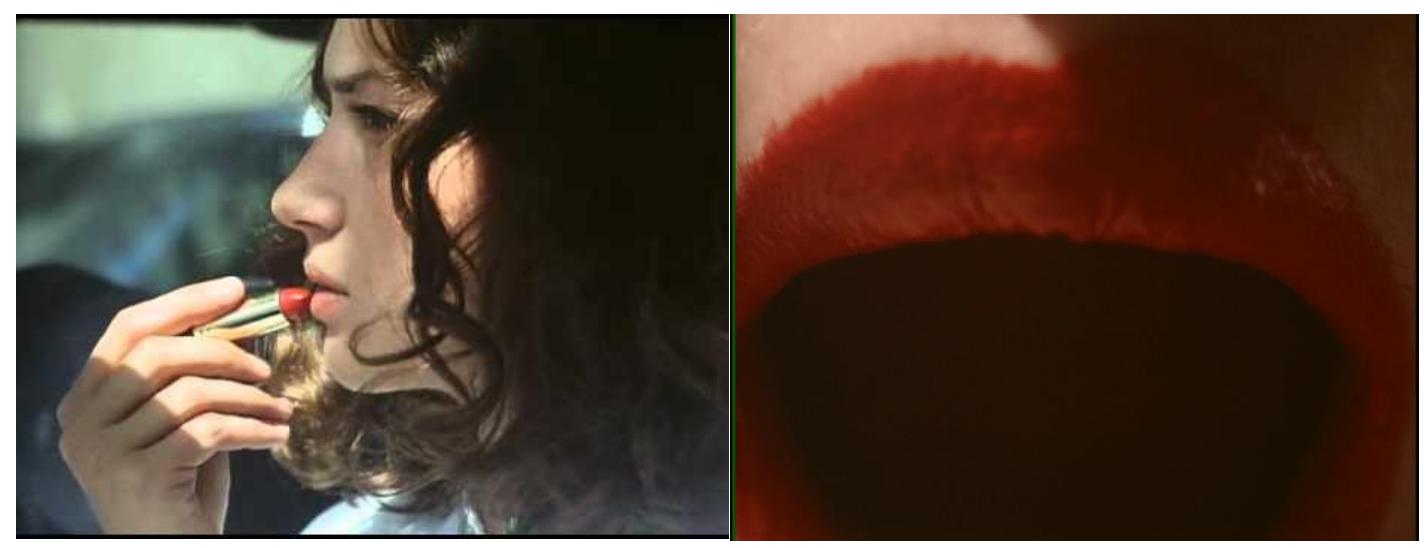

\section{Conclusão}

O ponto chave da definição batailleana está em colocar o erotismo como uma aventura psicológica. Trata-se de uma busca por sentido, a partir do momento em que o indivíduo põe em questionamento a própria existência. Cabe aqui uma outra definição de erotismo dada pelo autor: "O Erotismo é, na consciência do homem, o que coloca o ser em questão." Nesse 
questionamento se instaura um desequilíbrio, uma busca por um novo sentido para o próprio ser que se perdeu objetivamente. $\bigcirc$ "eu" se perde e busca se reencontrar e se identificar num objeto. Essa busca por um objeto que implante um novo sentido constitui o caminho do desejo.

Maria, inicialmente, questiona-se quanto ao grau de valor de sua existência a partir de sua primeira fala no filme: "Perguntava-me se algo importante ia ocorrer em minha vida." Há aqui o questionamento interior que abre para a experiência erótica sagrada. Maria recebe, em seu corpo, o fruto divino. Contudo, os constantes questionamentos sobre sua condição corpórea falam de como esse ser sagrado revela-se e envolve-se com o corpo da mulher. Há um prazer, mas também estranhamento. Para Bataille, o questionamento da própria existência é uma condição humana que está na base da experiência sagrada. Ao perceber suas limitações, sua mortalidade, a angústia se instala como dúvida, inadequação, busca por sentido. A insuficiência das operações cognitivas promoveriam, a partir dessa "experiência interior", o sentimento do desconhecido, o qual não é cognoscível. Assim, o sujeito viveria nesse paradoxo do desejo por conhecimento e na angústia de que nem tudo é dado a conhecer. A experiência sagrada seria esse encontro com o mistério.

Ao manter-se casta, Maria se dispõe ao desejo divino, mas esse desejo apropria-se do seu corpo, de forma que não se pode distanciar o sagrado da corporeidade. Eis então que se instala uma castidade erótica. Maria precisa vivenciar inteiramente seu corpo, sem o toque de outrem, para o encontro consigo mesma (condição que se coloca indispensável, para a experiência erótica com Deus). Numa gnose de si, em vez de resignar-se, Maria procura construir sua castidade, intimamente.

A aproximação semântica do sol ao ânus traduz a ininteligibilidade racional do sagrado vivido no íntimo de Maria. O reconhecimento da divindade opera-se na obscuridade dos orifícios corporais. Cansada de opor o corpo à alma, a jovem transmuta o a alma em corpo, uma vez que Deus utiliza-se da carne e seus mistérios para atuar sobre a alma. $O$ ser-mulher de Maria é corpo e a alma, e o amor divino se oferece ao entendimento na articulação da instância carnal com a espiritual. Contudo, o corpo, em imbricação com a alma, se revelou como instrumento principal, na poiesis fílmica, para se alcançar o eros divino.

\section{Referências}

A BÍBLIA de Jerusalém. São Paulo: Paulus, 2002.

BATAILlE, G.O ânus Solar. Tradução de Anibal Fernandes. Lisboa: Hiena, 1985. . L'Érotisme. Paris: Les Éditions Minuit, 2011.

Autêntica, 2015.

A literatura e o mal. Tradução de Fernando Scheibe. Belo Horizonte: JE VOUS salue, Marie. Direção de Jean-Luc Godard. Paris: JLG Films, 1984.

MALABRE, Natalie. "Je vous salue Marie de Jean-Luc Godard : modalités et enjeux d'um retour du religieux au cinema". Cahiers d'études du religieux. Recherches interdisciplinaires. Numéro spécial 2012. 
O sagrado erótico em Je vous salue, Marie, de Jean-Luc Godard

MARTIN, Marcel. A linguagem cinematográfica. Tradução de Paulo Neves. São Paulo: Brasiliense, 2013.

SCHOLLHAMMER, Karl Erik. Além do visível: o olhar da literatura. Rio de Janeiro: 7Letras, 2007. 